\title{
Pre-extension Demonstration of Animal Drawn Wheat Row Planter in Selected Districts of Arsi and West Arsi Zones
}

\author{
Aman Nebo Ashebir Tsegaye \\ Oromia Agricultural Research Institute, Asella Agricultural Engineering Research Center, \\ P.O.Box (06 Asella Ethiopia)
}

\begin{abstract}
The demonstration work was conducted in two purposively selected districts namely Hetosa from Arsi and Asasa and Adaba from West Arsi zones with the objectives of evaluating the productivity and profitability of the wheat row planter under farmers' management, creating awareness on the importance of the technology and improving farmers' knowledge and use of the technology in the study areas. Six kebeles were purposively selected based on their accessibility. A total of 140 participant of which $113(81 \%)$ were male and $27(19 \%)$ female were participated on both theoretical and practical training on wheat row planter technology. A total of six trial farmers (One from each FREG) hosted demonstration of wheat row planter. The demonstration results revealed that on average planting wheat by wheat row planter have an advantage of reducing time from 3.8 days to one day to plant one hectare of land by pair oxen. It also reduces labor required from 11.3persons to 3persons to complete one hectare of land. In addition to these, planting wheat by wheat row planter had yield advantage of four quintals over traditional one and reduced seed needed to plant one hectare of land from approximately $200 \mathrm{~kg}$ to $134 \mathrm{~kg}$. The feedbacks obtained from participant farmers and other stakeholders also indicated that the technology is useful and applicable. Thus, based the findings, the wheat row planter technology was recommended for further scaling up.
\end{abstract}

Keywords: Demonstration, Row planter, wheat

DOI: $10.7176 / \mathrm{JBAH} / 10-23-03$

Publication date: December $31^{\text {st }} 2020$

\section{Introduction}

In Ethiopia wheat is the most important food crop and accordingly the crop is grown on 1.63 million hectares annually. The annual production was estimated to 3.43 million tons which is $17 \%$ of total cereal crops production (CSA, 2014).The average national productivity is 2.01 tons per hectare which is one of the least productivity in the world compared to world average wheat productivity per hectare which is 4 tons.

In recent years, demand was growing for row planting implements and methods as farmers' awareness for row planting is developing from their own evolving traditional practices and extension advocacy. Many attempts for wheat and teff row planting are emerging as farmers in many places are trying out with undersigned items like 'masti' (designed for baking injera) and various bottles and other containers. With such traditional and unverified methods of row planting, dramatic increase in yield and reduction of the quantity of seed required has been reported by farmers, DAs and experts. The research study done by Tolosa et al, (2014) in highland and lowlands of Arsi zone also reported that there is significant yield difference between row planted and broadcasted wheat farm $(13.9 \%)$ in high lands but with low significant difference in lowland areas.

The problem of mechanizing the planting process in small-scale agriculture remains largely unsolved worldwide. It is assumed that in Africa on average not even one farmer out of 1,000 is using a planter on the animal traction or tractor mechanization levels. Ethiopia is also facing the same problem Tolosa et al, (2014).

Asella Agricultural Engineering Research Center developed wheat row planter which can solve this problem and also conducted participatory evaluation of different planters from different sources. Accordingly, OARI-Asela AMRC wheat row planter was selected for its minimum labor requirement, fertilizer application system, appropriate seed rate which is almost equivalent to recommend seed rate and time it takes to cover one hectare. The participant farmers during the evaluation process also preferred the OARI-Asela AMRC wheat row planter.

Therefore, this research is intended to demonstrate the wheat row planter in selected districts of Arsi and west Arsi zones.

\section{Objectives of the study}

$>$ To evaluate the performance and profitability of the wheat row planter under farmers' management

$>$ To create awareness on the importance of the technology

\section{Methodology}

\section{Site and farmer selection}

To conduct demonstration of wheat row planter first two districts namely Hetosa and Gedeb Asasa were purposively selected based on their representativeness and accessibility. From these districts, six kebels (three 
from each district) were selected. Then experimental sites and farmers were selected based on location, suitability for more farmers to visit the demonstration plot with DA and district experts. Six farmers' research groups (FRGs) were established to conduct this research activity.

\section{Technology evaluation and demonstration method/techniques}

Evaluation of wheat row planter was undertaken by comparing with traditional materials used for wheat row planting. Training and field day were arranged to enhance farmer to farmer learning and information exchange. To show the difference that happens due to use of the technology, the plots planted with row planter was compared with the one not planted with row planter.

\section{Data type and method of data collection}

Both qualitative and quantitative data were collected from primary and secondary sources. Primary data such as uniformity of seed dropped, time to cover one hectare, labor reduced, agronomic and yield data, economic return/profitability, total number of farmers participated in training, field visits and field days, number of farmers who become aware of the relative advantage of the technology, role of farmers and other stakeholders in technology demonstration, change in level of knowledge and skill of farmers and farmers' opinion were collected using field observation, household interview, focus group discussion and knowledge test.

\section{Method of data analysis}

This study used simple statistical analytical tools such as percentages, mean values and frequencies for data analysis.

\section{Results and Discursions \\ Training of farmers and stakeholders}

Training was given by multidisciplinary team of researchers composed of Engineers, Extensionist and Socioeconomist. On the training, a total of 140 participant of which $113(81 \%)$ were male and $27(19 \%)$ were female participated on both theoretical and practical training on wheat row planter technology. The training was mainly focused on how to operate technology and relative advantage of technology over local practice.

Table 1. Training given to farmers and other stakeholders on wheat row planter

\begin{tabular}{llcll}
\hline Disticts & Participants & Male & Female & Total \\
\hline Hetosa & Farmers & 45 & 15 & 60 \\
& Agricultural Experts & 3 & - & 3 \\
& Development agents & 3 & - & 3 \\
Gedeb Asasa & Supervisor & 2 & 2 & 4 \\
& Farmers & 50 & 10 & 60 \\
& Agricultural Experts & 4 & - & 4 \\
Grand total & Development agents & 3 & - & 3 \\
\hline & Supervisor & 3 & - & 3 \\
\end{tabular}

Time and labor required

The result in the following table 2 below shows that time taken to complete planting of one hectare land. The result showed that on average planting wheat by row planter minimized time required from 3.8 days to 1 day. In addition, planting wheat by row planter also reduced labor required to complete one hectare of land from 11.3 persons to 3 persons.

Table 2. Time and labor required to plant one hectare of land

\begin{tabular}{llccccccc}
\hline Wheat row planter & Description & Site1 & Site2 & Site3 & Site4 & Site5 & Site6 & Average \\
\cline { 2 - 9 } & Labor required & 3 & 3 & 3 & 3 & 3 & 3 & 3 \\
& Time taken & 1 & 1 & 1 & 1 & 1 & 1 & 1 \\
Local practice & Labor required & 12 & 12 & 8 & 12 & 12 & 12 & 11.3 \\
& Time taken & 4 & 4 & 3 & 4 & 4 & 4 & 3.8 \\
\hline
\end{tabular}

Sources: Own data

\section{Amount of seed required and yield obtained}

As shown in the following graph, the average amount of seed to plant one hectare of land using the improved row planter was $134 \mathrm{~kg}$. Whereas it was $300 \mathrm{~kg}$ when planting was done using local material. On average, planting wheat by wheat row planter had four quintals yield advantage over the planting by local materials. 


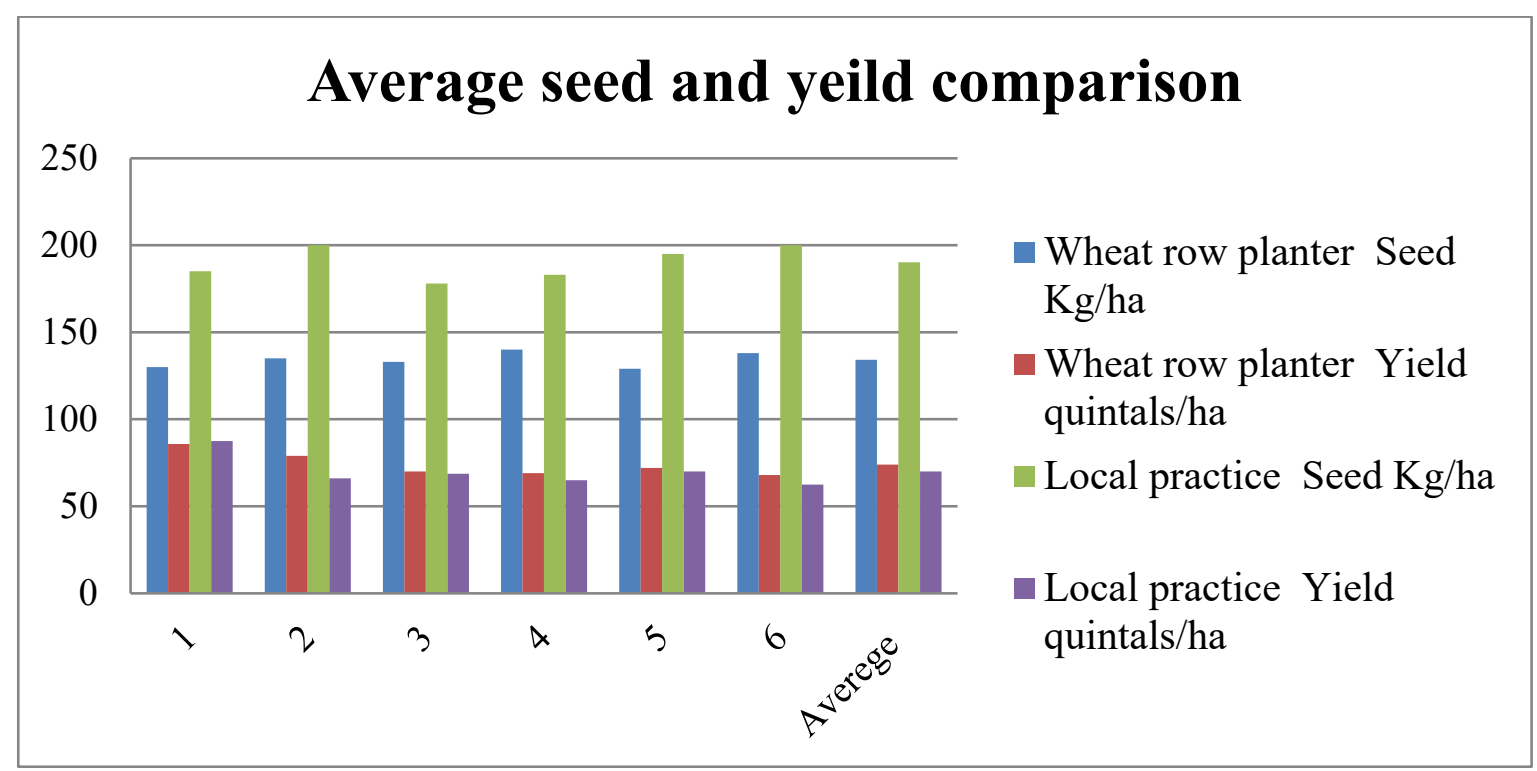

Graph1. Amount of seed required and yield obtained

Profitability analysis of animal drawn wheat planter

The Profitability analyses of animal drawn wheat planter was calculated using partial budget analysis which is useful tools in the decision process and manage to decide on alternative uses of resources. As result shown in the following table the net return obtained from deduction of increased income from increased cost due to introduction of animal drawn wheat row planter technology. Thus, wheat producer obtained net benefit of two thousand five hundred ninety birr from one hectare land.

Table 3: Economic analysis using partial budget analysis

\begin{tabular}{|c|c|}
\hline $\begin{array}{l}\text { Column } 1 \\
\text { Increased income due to change: }\end{array}$ & $\begin{array}{l}\text { Column } 2 \\
\text { Increased costs due to change: }\end{array}$ \\
\hline $\begin{array}{l}\text { Income increased due to increased yield: } \\
\text { 4quintals X } 1400 \mathrm{Birr}=5,600 \mathrm{Birr} / \text { day }\end{array}$ & $\begin{array}{l}\text { Cost increased due to purchase of machine: } \\
\qquad 5,000 \text { Birr }\end{array}$ \\
\hline Subtotal $=5,600 B i r r$ & Subtotal $=5,000$ Birr \\
\hline Reduced costs due to change: & Reduced income due to change: \\
\hline Reduced labor cost: & \\
\hline 8 Person X 80Birr $=640 B i r r /$ hec. & \\
\hline Cost of seed: $66 \mathrm{~kg} \mathrm{X} 15 \mathrm{Birr}=990$ Birr & \\
\hline $\begin{array}{l}\text { Reduced cost of oxen: } \\
\text { 6oxen } X 60 \mathrm{Birr}=360 \mathrm{Bir} / \mathrm{hec}\end{array}$ & \\
\hline Subtotal = 7,590 Birr & Subtotal $=0$ Birr \\
\hline $\begin{array}{l}\text { Change in income: } \\
\text { (subtotal from Column } 1 \text { minus subtotal Column 2) } \\
\mathbf{7 , 5 9 0}-\mathbf{5 , 0 0 0}=(\mathbf{2 , 5 9 0})\end{array}$ & \\
\hline
\end{tabular}

Framers` feedbacks and reaction

In the process of demonstrating wheat row planter mini-field day was organized. During the field day, different stakeholders such as hosting farmers, non-hosting farmers, development agents, supervisors, experts and researchers gave their own feedbacks depending on what they observed during operation and by comparing it with traditional wheat planting. Participant farmers appreciated the demonstrated row planter for reducing labor and time required, seed use efficiency and additional yield obtained as a result of using the improved row planter.

\section{Conclusions and recommendations}

The demonstration results revealed that on average planting wheat by wheat row planter have an advantage of reducing time from 3.8 days to one day to plant one hectare of land by pair oxen. It also reduces labor required from 11.3persons to 3persons to complete one hectare of land. In addition to these, planting wheat by wheat row planter had yield advantage of four quintals over traditional one and reduced seed needed to plant one hectare of land from approximately $200 \mathrm{~kg}$ to $134 \mathrm{~kg}$. The feedbacks obtained from participant farmers and other stakeholders also indicated that the technology is useful and applicable. 


\section{References}

CSA (Central Statistical Agency) (2018). Area and Production of Major Crops. Federal Democratic Republic of Ethiopia Central Statistical Agency, Addis Ababa, Ethiopia.

Tolesa A., Bezabih E., Jema H., and Belaineh L. Impact of Wheat Row Planting on Yield of Smallholders in Selected Highland and Lowland Areas of Ethiopia. International Journal of Agriculture and Forestry. 4 (5): pp. 386-393 2014. 